Zeszyty Naukowe Szkoły Głównej Gospodarstwa Wiejskiego w Warszawie Problemy Rolnictwa Światowego tom 17 (XXXII), zeszyt 3, 2017: 239-248

DOI: 10.22630/PRS.2017.17.3.70

Tomasz Rokicki' ${ }^{1}$, Magdalena Golonko² ${ }^{2}$ Aleksandra Perkowska ${ }^{3}$

Szkoła Gówna Gospodarstwa Wiejskiego w Warszawie

\title{
Regionalizacja rolnictwa na świecie
}

\section{Regionalization of Agriculture around the World}

\begin{abstract}
Synopsis. Celem głównym badań była ocena regionalizacji produkcji rolniczej na świecie oraz występującym $\mathrm{w}$ tym aspekcie zmian. W artykule przedstawiono wartość produkcji rolnictwa w regionach świata określanych przez kontynenty. Źródłem materiałów były dane z FAOSTAT. Okres badań dotyczył lat 2007-2014. Wartość światowej produkcji rolniczej stale wzrastała. Jedynie w momencie kryzysu gospodarczego w 2009 roku oraz w 2014 roku zaobserwowano spadki we wszystkich obszarach poza Azją. Zauważono, że występowała duża koncentracja produkcji rolniczej, która była skupiona w Azji i Europie. Następowało stopniowe przenoszenie się produkcji z Europy i Ameryki Północnej do Azji i Ameryki Południowej. Prawidłowości te zostały potwierdzone również przy analizie poszczególnych grup produktów rolnych, jak zboża i produkty zwierzęce. Jednocześnie stwierdzono bardzo dużą koncentrację i występowanie dużego zróżnicowania produkcji rolniczej w regionach. Dysproporcje wzrastały szybciej w przypadku produktów żywnościowych niż nieżywnościowych wytworzonych w rolnictwie.
\end{abstract}

Slowa kluczowe: globalizacja, regionalizacja rolnictwa, produkcja rolnicza na świecie

\begin{abstract}
The aim of the study was to assess the regionalization of agricultural production around the world and the changes that have occurred in this respect. The article presents the value of agricultural production in regions of the world defined by the continents. The source of the material was data from FAOSTAT. The period of research covered the years 2007-2014. The value of world agricultural production has steadily increased. Only at the time of the economic crisis in 2009 and in 2014 were declines seen in all areas other than Asia. There was a high concentration of agricultural production in Asia and Europe. There was a gradual relocation of production from Europe and North America to Asia and South America. These regularities have been confirmed also in the analysis of individual groups of agricultural products like cereals and animal products. At the same time, there was a very high concentration and a high degree of variation in agricultural production in the regions. Disproportions increased faster in food products than non-food products produced in agriculture.
\end{abstract}

Key words: globalization, regionalization of agriculture, agricultural production around the world

\section{Wprowadzenie}

Globalizacja powszechnie uważana jest za zjawisko nowe, związane z wydarzeniami na przełomie XIX i XX wieku. Na rozwój globalizacji bezpośredni wpływ miała rewolucja techniczno-informacyjna, rozwój komputeryzacji, łączności satelitarnej oraz Internetu. Kolejnym czynnikiem dynamizującym proces globalizacji były przemiany systemowe w Europie Środkowej i Wschodniej związane z upadkiem komunizmu. Trzecią przyczyną

\footnotetext{
${ }^{1}$ dr inż., Katedra Logistyki SGGW wWarszawie, ul. Nowoursynowska 166, 02-787 Warszawa, e-mail: tomasz_rokicki@sggw.pl

${ }^{2}$ mgr, Katedra Logistyki SGGW wWarszawie, ul. Nowoursynowska 166, 02-787 Warszawa, e-mail: magdalena_wiluk@sggw.pl

${ }^{3}$ mgr, Katedra Logistyki SGGW wWarszawie, ul. Nowoursynowska 166, 02-787 Warszawa,

e-mail: aleksandra_perkowska@sggw.pl
} 
były zmiany struktur ekonomicznych dotyczących decentralizacji i prywatyzacji (Budnikowski, 2003).

Wielkie odkrycia geograficzne na przełomie XV i XVI w. przyczyniły się do rozwoju handlu oraz kapitalizmu jako ustroju, kształtując w ten sposób ekonomiczne podstawy gospodarki rynkowej. Ideologia liberalizmu, zwalczająca ograniczenia i przywileje pozwoliła w epoce oświecenia na popularyzację zasad gospodarki rynkowej, w której w rozpowszechnianiu zasadniczą rolę odegrały rewolucja francuska oraz amerykańska. W rezultacie nastapiło szybkie uprzemysłowienie gospodarki światowej, a możliwości masowego wytwarzania pobudziły rozwój handlu, co doprowadziło do natychmiastowego postępu technicznego. Dało to podstawy do rozwoju wymiany międzykontynentalnej. Dla rozwoju procesów globalizacyjnych szczególne znaczenie miał kryzys gospodarczy w 1873 r., który osłabiając tendencje internacjonalizacyjne rozpoczął tym samym erę wielkiej przedsiębiorczości. Wielkie firmy działające na światowym rynku podzieliły go między siebie i rozpoczęły swoją działalność jedynie w krajach należących do centrum kapitalistycznego świata, tj. w Wielkiej Brytanii, Niemczech, Francji, Japonii i Stanach Zjednoczonych. Kraje Azji, Europy Wschodniej oraz Ameryki Południowej stanowiły tzw. peryferie opierające swoje gospodarki na naśladowaniu liderów. Z obszarów rozwiniętych płynął kapitał, wszelkie wzorce konsumpcji, rozwiązania techniczne, a także system budowania instytucji. Rozwinięcie działalności gigantycznych firm na peryferiach uznawane jest za realizację idei globalizacji (Rosińska-Bukowska, 2009).

W ostatnim dwudziestopięcioleciu rolnictwo wielu krajów przeszło wiele istotnych zmian i procesów. Nastąpił wzrost produkcji, zwiększenie produkcyjności rolnictwa, a także wzrost efektywności wykorzystania nakładów. Zaobserwowano kurczenie się gospodarczej roli rolnictwa w gospodarce narodowej i lokalnej, nastąpiło nasilenie konkurencyjności międzynarodowej i międzysektorowej. Nastąpił wzrost świadomości konsumentów na temat jakości i bezpieczeństwa żywności, wzrost znaczenia postępu rolniczego oraz poszerzanie i popularyzacja wiedzy z zakresu procesów produkcyjnych. Społeczeństwo zainteresowało się wielofunkcyjnością rolnictwa i pozarolniczych form gospodarowania na terenach wiejskich oraz uświadomiło sobie potrzeby oparcia rozwoju rolnictwa na koncepcji zrównoważonego rozwoju. Nastąpiło słabnięcie politycznego i społecznego poparcia dla interwencjonalizmu rolniczego, polityki protekcjonizmu oraz subsydiowania (Adamowicz, 2008).

Globalizacja i regionalizacja są efektem internacjonalizacji gospodarki i wpływają na kształtowanie współczesnych międzynarodowych stosunków ekonomicznych (Żołądkiewicz 2012). Globalizacja jest terminem ideą, ale i materialnym procesem, który powoduje np. ujednolicenie zasad handlu produktami rolnymi, czy też określa radykalnie złożone stosunki władzy i ich skutki na wzajemne relacje w wymianie towarów na świecie (Argent 2011) Region tworzy wydzielony, dość jednorodny obszar, który odróżnia się od terenów przyległych określonymi cechami. Region może być wyodrębniony na podstawie kryteriów geograficznych, ekonomicznych, politycznych oraz kulturowych (Lubbe, 2010).

Procesy globalizacji i regionalizacji stanowią istotny czynnik wpływający na rozwój rolnictwa (Sapa 2010). W literaturze można spotkać twierdzenia autorów uważających globalizację za niekompletną z powodu pominięcia rynków pracy oraz pozostawienia $\mathrm{w}$ tyle z liberalizacją sektora rolnego (Kołodko 2008). Rolnictwo dotychczas zostało objęte przez globalizację $\mathrm{W}$ małym stopniu $\mathrm{z}$ powodu braku swobody przepływu artykułów rolnych. Sektor ten uczestniczy w procesach globalizacji nie przez procesy produkcji i obrotu surowcami rolnymi, ale przez efekty wytwórcze przemysłu przetwórczego oraz pozostałe segmenty agrobiznesu (Sobiecki, 2007; Rigg, 2006). 
Sprawny, międzykontynentalny przepływ towarów doprowadził do zatrzymania produkcji rolnej na obszarach o utrudnionych warunkach klimatycznych i do zwiększenia importu taniej żywności. Skutkiem takich zachowań była presja jaką powodowały kraje posiadające korzystne warunki do produkcji rolniczej oraz niskie koszty produkcji na zniesienie ograniczeń $\mathrm{w}$ handlu, a także obniżenie cen rolnych. Dotknęło to przede wszystkim Europę, na którą presję wywierają Stany Zjednoczone wraz z Kanadą, kraje Ameryki Południowej oraz Australia i Nowa Zelandia. Proces globalizacji niesie za sobą zadanie polegające na upowszechnianiu nowoczesnych biotechnologii, których przykładem są organizmy genetycznie modyfikowane (Adamowicz 2008).Pozwoliły one na realizację wielu programów rozwoju rolnictwa $\mathrm{z}$ zakresu zielonej rewolucji, której opiekunem była agencja ONZ - Organizacja do spraw Wyżywienia i Rolnictwa (FAO) (Anioł, Bielecki, Twardowski, 2008). Efektem zielonej rewolucji było zwiększenie produkcji rolniczej i co za tym idzie złagodzenie problemu głodu i niedożywienia. Współcześnie użycie organizmów genetycznie modyfikowanych jest następnym etapem zielonej rewolucji. W Indiach owa rewolucja pozwoliła na wzrost spożycia żywności (zboża, rośliny oleiste, ryby, mleko, owoce i warzywa) i osiągnięcie wystarczającego poziomu jakościowego i ilościowego żywności. Zielona rewolucja mimo różnych kontrowersji była niezwykle istotnym krokiem w rozwoju rolnictwa (Adamowicz 2008).

\section{Materiał i metodyka badań}

Celem głównym badań była ocena regionalizacji produkcji rolniczej na świecie oraz występującym w tym aspekcie zmian. Celami szczegółowymi było przedstawienie stopnia koncentracji produkcji rolniczej, wskazanie regionów z dominującym udziałem tej produkcji na świecie, określenie kierunków i siły zmian w tym zakresie w poszczególnych obszarach świata. Do badań jako regiony przyjęto kontynenty. Źródła materiałów stanowią dane publikowane przez FAOSTAT. Okres badawczy obejmował lata 2007-2014. W pracy wykorzystano metodę porównawczą, posługiwano się wskaźnikami dynamiki, obliczono współczynnik koncentracji Giniego oraz przedstawiono stopień koncentracji za pomocą krzywej Lorenza. Do prezentacji wyników badań zastosowano metodę opisową, tabelaryczna i graficzną.

\section{Wyniki badań}

W latach 2007-2014 wartość światowej produkcji końcowej brutto rolnictwa wyrażona w USD zwiększyła się o $55 \%$ z 2 do 3,1 bilionów USD. Jedynie w momencie wystąpienia kryzysu gospodarczego w 2009 roku oraz w 2014 roku nastąpił spadek wartości produkcji rolnictwa (tab. 1). W poszczególnych regionach światach występowały podobne prawidłowości, z niewielkimi różnicami. W czasie kryzysu gospodarczego produkcja rolnicza wzrosła jedynie w Azji. Najmocniej konsekwencja załamania gospodarczego były widoczne w rolnictwie Afryki i Europy. W latach 2007-2014 podwoiła się wartość produkcji rolnictwa w Ameryce Południowej, ale było to spowodowane bardzo dobrymi wynikami w 2008 roku, ale też w latach bezpośrednio następujących po kryzysie gospodarczym (20102011). Duży wzrost odnotowano też w Oceanii (o 73\%) i Azji (o 69\%). Z kolei najwolniej rosła wartość produkcji rolniczej w Europie, bo zwiększyła się jedynie o 15\%. Spowodowane 
to było występowanie kwot produkcyjnych w odniesieniu do wielu produktów rolnych oraz prowadzoną polityką rolną. Mały przyrost wartości produkcji rolniczej odnotowano też w Ameryce Północnej (o 25\%).

Tabela 1. Wskaźniki dynamiki o podstawie zmiennej dla wartości produkcji rolniczej na świecie w latach 2008-2015 (rok poprzedni $=100)$

Table 1. Changes in agriculture production value in the world in 2008-2015 (previous year $=100$ )

\begin{tabular}{l|ccccccc}
\hline \multirow{2}{*}{ Regiony } & \multicolumn{5}{c}{ Wskaźniki dynamiki łańcuchowe w latach $2008-2014$ (rok poprzedni=100) } \\
& 2008 & 2009 & 2010 & 2011 & 2012 & 2013 & 2014 \\
\hline Afryka & 135,30 & 75,70 & 126,53 & 107,47 & 102,48 & 101,42 & 95,93 \\
Ameryka Północna & 105,20 & 89,65 & 119,17 & 112,77 & 105,12 & 98,97 & 94,59 \\
Ameryka Południowa & 131,94 & 90,31 & 123,65 & 123,33 & 98,15 & 107,17 & 103,81 \\
Azja & 114,64 & 101,20 & 119,03 & 120,68 & 101,78 & 101,99 & 97,44 \\
Europa & 116,81 & 77,11 & 107,63 & 121,30 & 92,03 & 109,49 & 96,93 \\
Oceania & 134,38 & 80,05 & 113,89 & 146,47 & 107,48 & 93,26 & 96,00 \\
Świat & 117,07 & 91,71 & 118,08 & 119,21 & 100,58 & 102,86 & 97,51 \\
\hline
\end{tabular}

Źródło: opracowanie własne na podstawie danych FAOSTAT.

Oprócz tempa zmian ważny jest udział poszczególnych regionów określanych przez kontynenty. Zdecydowanie największa była wartość produkcji rolniczej wytwarzanej w Azji, bo wynosiła ona w 2007 roku 51,9\%, zaś w 2014 roku już 57,4\% (rys. 1). Na kolejnym miejscu znajdowała się Europa, której udział jednak systematycznie spadał z 18,6\% do 14,0\% w latach 2007-2014. Spadek następował też w Ameryce Północnej z 11,2 do 9,1\%. Z kolei znaczenie rolnictwa Ameryki Południowej zwiększało się, o czym świadczy wzrost udziału w światowej produkcji rolnictwa z 6,7\% w 2007 roku do 8,8\% w 2014 roku. Następowało więc stopniowe przenoszenie się produkcji rolniczej do obszarów posiadających korzystne warunki przyrodnicze i produkujących tanio. Oczywiście przy tego typu porównaniach należy pamiętać o różnych potencjałach poszczególnych kontynentów, głównie w zakresie wolumenu powierzchni gruntów rolniczych.

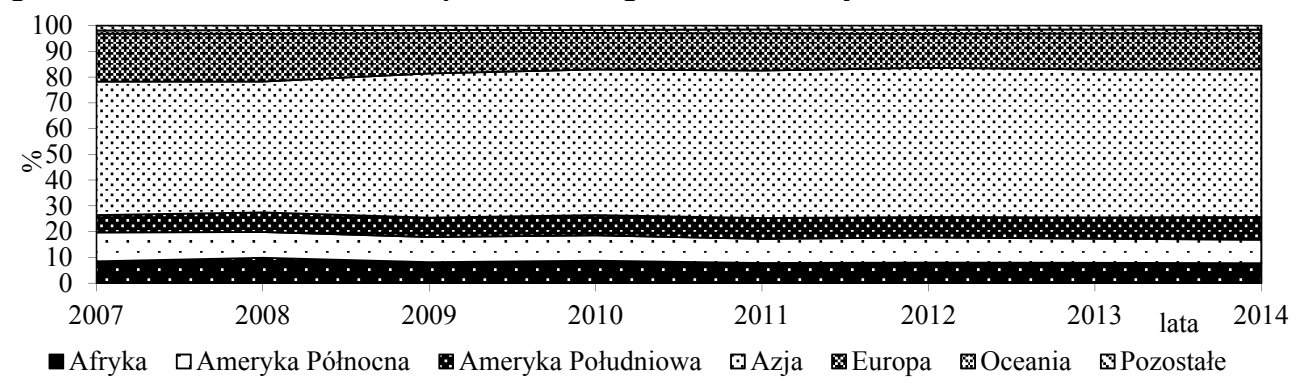

Rys. 1. Udział regionów świata w produkcji rolniczej w latach 2007-2015 (\%)

Fig. 1. Share of world regions in agricultural production in 2007-2015 (\%)

Źródło: jak w tab. 1.

Do określenia stopnia koncentracji produkcji rolniczej na świecie zastosowano współczynnik Giniego. Dane dotyczyły lat 2007-2014, zaś liczba obserwacji wynosiła 48. 
Współczynnik Giniego obliczony z próby wyniósł 0,52 , zaś estymowany współczynnik dla populacji 0,53. Oznacza to bardzo dużą koncentrację produkcji rolniczej i zróżnicowanie występujące na świecie. Dodatkowo te zróżnicowanie przedstawiona krzywa koncentracji Lorenza (rys. 2). Występował jeden region (Azja), który wytwarzał ponad 50\% światowej produkcji rolniczej. Z kolei w Oceanii było to mniej niż $2 \%$, podobnie w Ameryce Środkowej. Koncentracja produkcji rolniczej będzie następowała dalej, głównie za sprawą różnych regulacji i polityk rolnych stosowanych na poszczególnych kontynentach i w indywidualnych państwach.

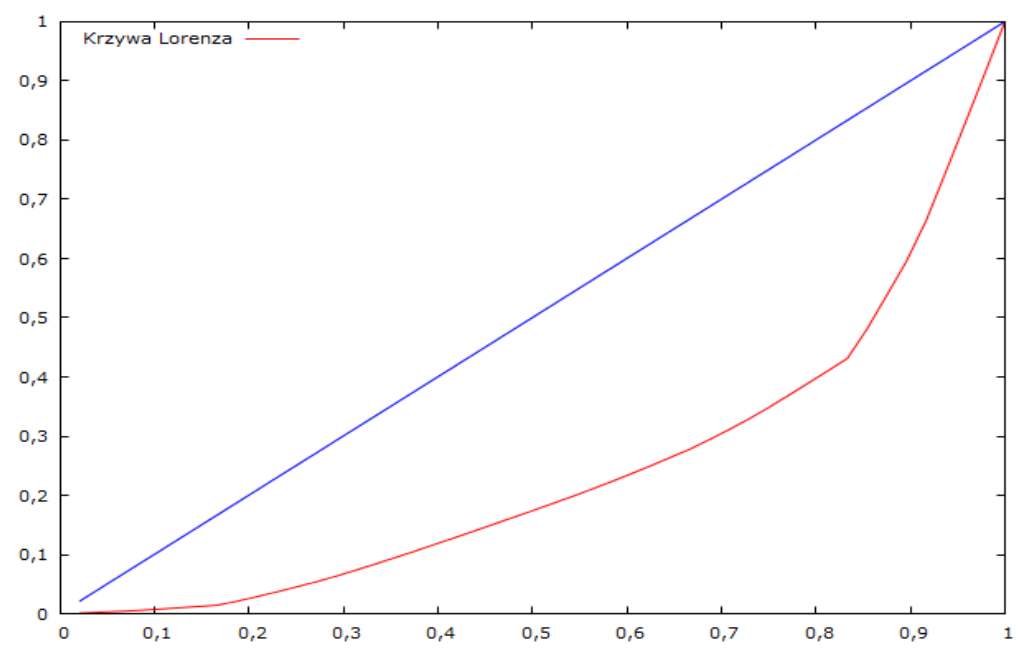

Rys. 2. Krzywa koncentracji Lorenza dla wartości produkcji rolniczej w regionach świata w latach 2007-2015

Fig. 2. Lorenz concentration curve for the value of agricultural production in the regions of the world in the years 2007-2015

Źródło: jak w tab. 1.

Poszczególne kontynenty, ale też i kraje, specjalizują się w wytwarzaniu danych płodów rolnych. Decydujące znaczenie mają warunki przyrodnicze. Grupą produktów o dominującym znaczeniu w produkcji rolniczej są zboża. Ich wartość produkcji wzrosła w latach $2007-2014$ o 56\% z 532 mld do 832 mld USD. Tempo wzrostu było więc tożsame z występującym w odniesieniu do całej produkcji rolniczej. Podwojenie wartości produkcji zbóż nastąpiło w Oceanii (wzrost o 111\%). Duży wzrost odnotowano tez w Azji (86\%) i Ameryce Południowej (66\%). Z kolei spadek produkcji o 1,5\% wystąpił w Ameryce Południowej. W Europie odnotowano bardzo mały wzrost, bo o $18 \%$. Duże znaczenie w tej produkcji mają uregulowania i polityka rolna, ale też wystąpienie korzystnych lub niekorzystnych warunków do wzrostu i zbioru zbóż w poszczególnych latach. Najbardziej kryzysowy był 2009 roku. Wówczas jedynie w Azji wzrosła wartość produkcji zbóż. W pozostałych regionach świata odnotowano spadki, największe w Europie (o 40\%), Ameryce Południowej i Oceanii (po 31\%). Takie spadki były konsekwencją kryzysu gospodarczego. Trudniejszy był też 2014 rok, gdy we wszystkich regionach świata, poza Oceanią, wartość produkcji zbóż zmniejszyła się. 
Tabela 2. Wskaźniki dynamiki o podstawie zmiennej dla wartości produkcji zbóż na świecie w latach 2008-2015 (rok poprzedni $=100)$

Table 2. Changes in cereals production value in the world in 2008-2015 (previous year $=100$ )

\begin{tabular}{l|ccccccc}
\hline \multirow{2}{*}{ Regiony } & \multicolumn{6}{c}{ Wskaźniki dynamiki łańcuchowe w latach } & 2008-2014 (rok poprzedni=100) \\
& 2008 & 2009 & 2010 & 2011 & 2012 & 2013 & 2014 \\
\hline Afryka & 163,71 & 72,81 & 107,40 & 107,26 & 110,86 & 101,05 & 94,06 \\
Ameryka Północna & 105,45 & 83,55 & 126,05 & 118,58 & 103,48 & 89,16 & 81,01 \\
Ameryka Południowa & 145,05 & 69,66 & 119,37 & 137,09 & 101,20 & 108,70 & 91,00 \\
Azja & 116,18 & 102,17 & 114,03 & 126,45 & 104,27 & 108,26 & 96,13 \\
Europa & 130,88 & 60,13 & 109,27 & 148,30 & 94,29 & 104,25 & 94,38 \\
Oceania & 207,54 & 69,21 & 90,05 & 156,32 & 100,00 & 101,83 & 102,51 \\
Świat & 122,34 & 86,91 & 114,41 & 127,23 & 103,02 & 104,46 & 93,90 \\
\hline
\end{tabular}

Źródło: opracowanie własne na podstawie danych FAOSTAT.

W przypadku zbóż również następowało zjawisko koncentracji produkcji w Azji, gdyż udział tego regionu w światowej produkcji wzrósł w latach 2007-2014 z 54,3\% do 64,4\% (rys. 3). Szczególnie duże zmiany w strukturze produkcji zbóż były widoczne w 2009 roku. Zmniejszało się systematycznie znaczenie Ameryki Północnej (z 15,3\% do 9,6\% w latach 2007-2014) i Europy (z 16,4 do 12,4\%). Udział Afryki i Ameryki Południowej w produkcji zbóż był stabilny. W Oceanii odnotowano największą dynamikę wzrostu produkcji zbóż, jednak udział tego regionu w światowej produkcji był mniejszy niż $2 \%$.

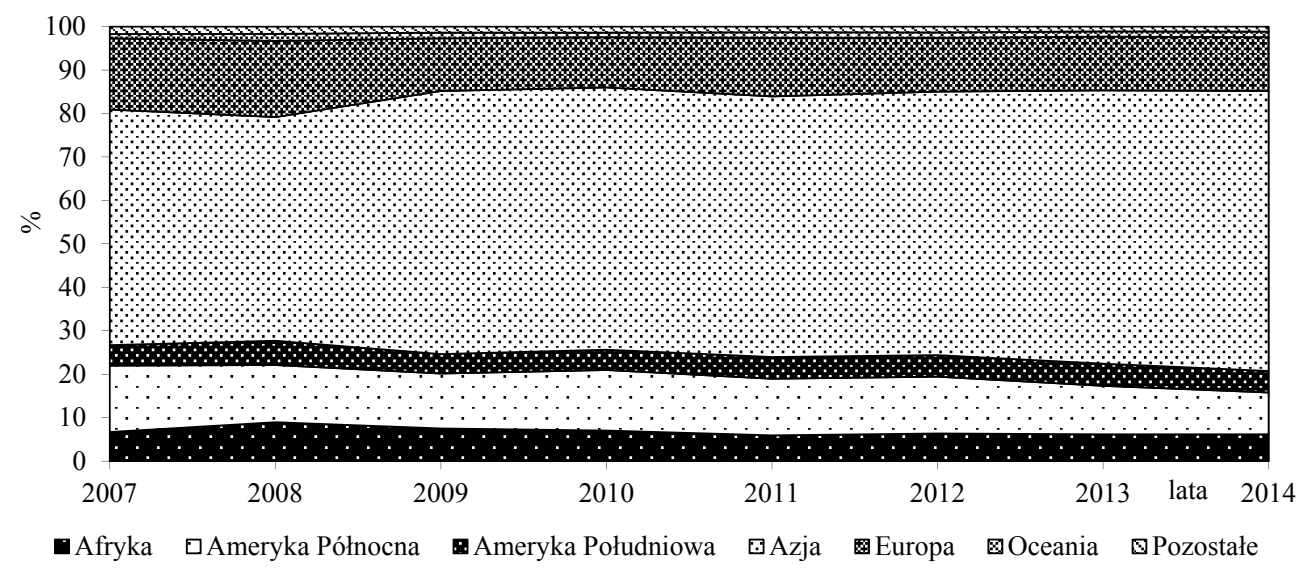

Rys. 3. Udział regionów świata w produkcji zbóż w latach 2007-2015 (\%)

Fig. 3. Share of world regions in cereals production in 2007-2015 (\%)

Źródło: jak w tab. 1.

Kolejną ważną grupą są produkty zwierzęce. Ich wartość produkcji na świecie zwiększyła się w latach 2007-2014 o 36,7\% z 380 do 519 mld USD. Produkcja ta podwoiła się w Ameryce Południowej (wzrost o 131\%), Oceanii (o 97\%), zaś najmniejszy jej wzrost nastąpił w Afryce (o 22\%) i Europie (o 23\%). Podobnie, jak dla produkcji ogółem i zbóż, największe spadki wartości produkcji zwierzęcej wystąpiły w 2009 roku (tab. 3) w Azji 
odnotowano wzrost o 2\%. Kolejne trudności były w 2012 roku, gdy jedynie w Ameryce Południowej odnotowano wzrost. Szczególnie korzystne dla produkcji zwierzęcej były lata 2010-2011. W przypadku produkcji zwierzęcej na jej wartość oprócz czynników rynkowych wpływają również uwarunkowania produkcyjne, jak np. dostępność pasz.

Tabela 3. Wskaźniki dynamiki o podstawie zmiennej dla wartości produkcji zwierzęcej na świecie w latach 2008$2015($ rok poprzedni $=100)$

Table 3. Changes in animal production value in the world in 2008-2015 (previous year $=100$ )

\begin{tabular}{l|ccccccc}
\hline \multirow{2}{*}{ Regiony } & \multicolumn{5}{c}{ Wskaźniki dynamiki łańcuchowe w latach 2008-2014 (rok poprzedni=100) } \\
& 2008 & 2009 & 2010 & 2011 & 2012 & 2013 & 2014 \\
\hline Afryka & 118,42 & 99,51 & 110,03 & 107,36 & 88,71 & 97,67 & 100,99 \\
Ameryka Północna & 102,97 & 74,06 & 119,07 & 125,09 & 96,54 & 107,66 & 118,75 \\
Ameryka Południowa & 132,51 & 94,09 & 125,98 & 120,05 & 100,43 & 109,50 & 111,30 \\
Azja & 100,29 & 102,15 & 112,94 & 114,50 & 98,40 & 102,78 & 98,00 \\
Europa & 119,24 & 77,18 & 108,52 & 115,75 & 94,66 & 109,43 & 102,57 \\
Oceania & 136,88 & 73,03 & 124,26 & 138,16 & 98,36 & 93,07 & 125,59 \\
Świat & 109,68 & 89,45 & 113,22 & 116,41 & 97,06 & 105,16 & 103,56 \\
\hline
\end{tabular}

Źródło: opracowanie własne na podstawie danych FAOSTAT.

Produkcja zwierzęce była skoncentrowana w Azji, jednak przewaga tego regionu nie była już tak duża (rys. 4). Udział Azji w światowej produkcji zwierzęcej wynosił około 43$45 \%$. Duże znaczenie miała też Europa, w której wytwarzano $25-28 \%$ tej produkcji. Ponad 10\% udział przypadał na Amerykę Północną. W przypadku produkcji zwierzęcej zmniejszał się udział Azji i Europy, zaś zwiększał Ameryki Południowej i Oceanii, które miały dobre warunki do ekstensywnego i taniego chowu zwierząt. Zmiany te były jednak bardzo powolne.

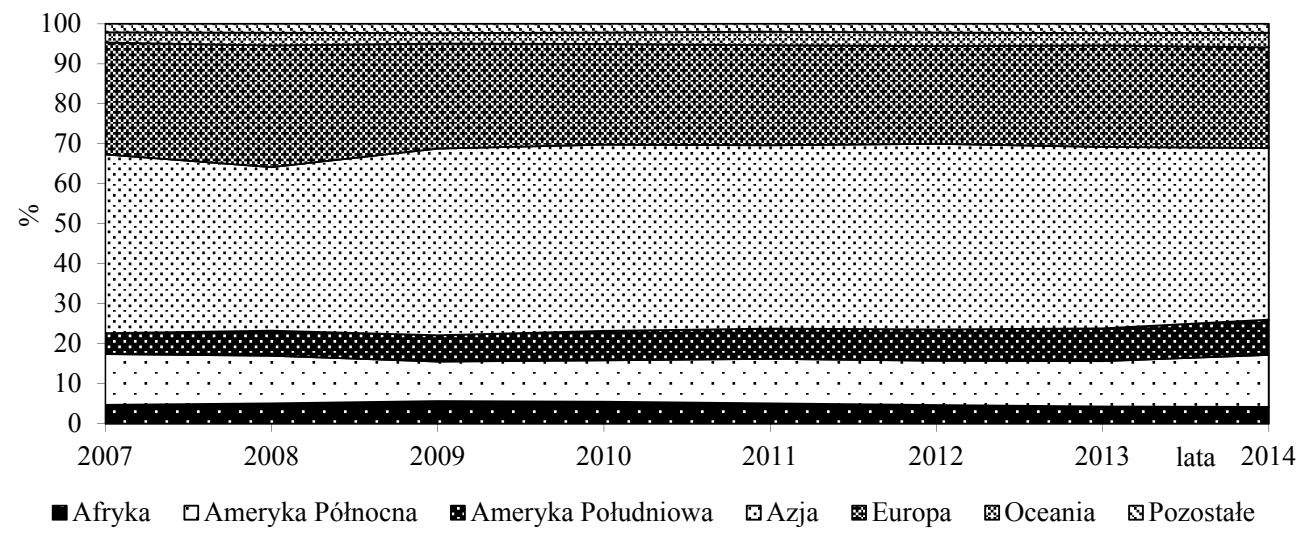

Rys. 4 Udział regionów świata w produkcji zwierzęcej w latach 2007-2015 (\%)

Fig. 4 Share of world regions in animal production in 2007-2015 (\%)

Źródło: jak w tab. 1 . 
Zdecydowana większość wytworzonej produkcji rolniczej przeznaczana była na potrzeby żywnościowe. W latach 2008-2014 było to około 95-96\% całkowitej produkcji. Przedstawianie statystyk dla takiej grupy produktów jest niecelowe, bo wartość produkcji, jej koncentracja i kierunki zmian były analogiczne jak dla produkcji rolniczej ogółem. Przedstawiono więc jedynie analizę odnośnie produktów nieżywnościowych rolnictwa, które mogą zyskiwać większe znaczenie w przypadku coraz większej wydajności rolnictwa. Do produktów nieżywnościowych zalicza się m.in. olej napędowy, tzw. biodiesel $\mathrm{z}$ przetworzonych płodów rolnych, ubrania i tkaniny z bawełny, wełny, lnu, banana manilskiego, juty, kokonów jedwabników oraz innych surowców, obuwie ze skór zwierząt, naturalna guma, kauczuk, wosk, herbata, tytoń. Produkcja surowców nieżywnościowych pochodzenia rolnego wzrosła na świecie w latach 2007-2014 o 50\% z 84 do 126 mld USD. Było to tempo odpowiadające produktom żywnościowym. Największy wzrost odnotowano w Ameryce Południowej (o 90\%), a w dalszej kolejności w Azji (55\%) i Afryce (41\%). Z kolei najniższy wzrost produkcji rolniczej nieżywnościowej był w Ameryce Północnej (o3\%) i w Europie (14\%). Kryzys gospodarczy w 2009 roku właściwie nie wpłynął na wartość tej produkcji (tab. 4). Gorsze były lata 2012-2014, gdy wartość produkcji nieżywnościowej $\mathrm{z}$ rolnictwa systematycznie zmniejszała się $\mathrm{w}$ większości regionów. W 2012 roku jedynie w Oceanii osiągnięto wzrost wartości tej produkcji, w 2013 roku w Europie, zaś w 2014 roku w Afryce, Ameryce Północnej i Południowej. Duży wpływ na osiągane wyniki mogą mieć uwarunkowania przyrodnicze w poszczególnych latach. Dodatkowo trzeba nadmienić, że niektóre produkty nieżywnościowe są uzyskiwane tylko w określonych obszarach świata.

Tabela 4. Wskaźniki dynamiki o podstawie zmiennej dla wartości produkcji nieżywnościowej rolnictwa na świecie w latach 2008-2015 (rok poprzedni $=100$ )

Table 4. Changes in non food production value in the world in 2008-2015 (previous year $=100$ )

\begin{tabular}{l|ccccccc}
\hline \multirow{2}{*}{ Regiony } & \multicolumn{7}{c}{ Wskaźniki dynamiki łańcuchowe w latach 2008-2014 (rok poprzedni=100) } \\
& 2008 & 2009 & 2010 & 2011 & 2012 & 2013 & 2014 \\
\hline Afryka & 107,61 & 80,92 & 176,67 & 95,64 & 91,31 & 91,79 & 114,34 \\
Ameryka Północna & 70,45 & 111,49 & 154,27 & 94,99 & 96,65 & 89,57 & 103,22 \\
Ameryka Południowa & 129,10 & 98,41 & 136,70 & 137,33 & 82,85 & 85,33 & 112,89 \\
Azja & 106,11 & 97,43 & 124,38 & 145,28 & 88,77 & 100,35 & 93,04 \\
Europa & 109,92 & 100,78 & 111,10 & 106,73 & 93,56 & 105,94 & 87,42 \\
Oceania & 77,62 & 120,80 & 131,12 & 214,64 & 131,71 & 72,47 & 49,40 \\
Świat & 103,98 & 98,30 & 130,18 & 139,41 & 91,61 & 94,53 & 93,29 \\
\hline
\end{tabular}

Źródło: opracowanie własne na podstawie danych FAOSTAT. 


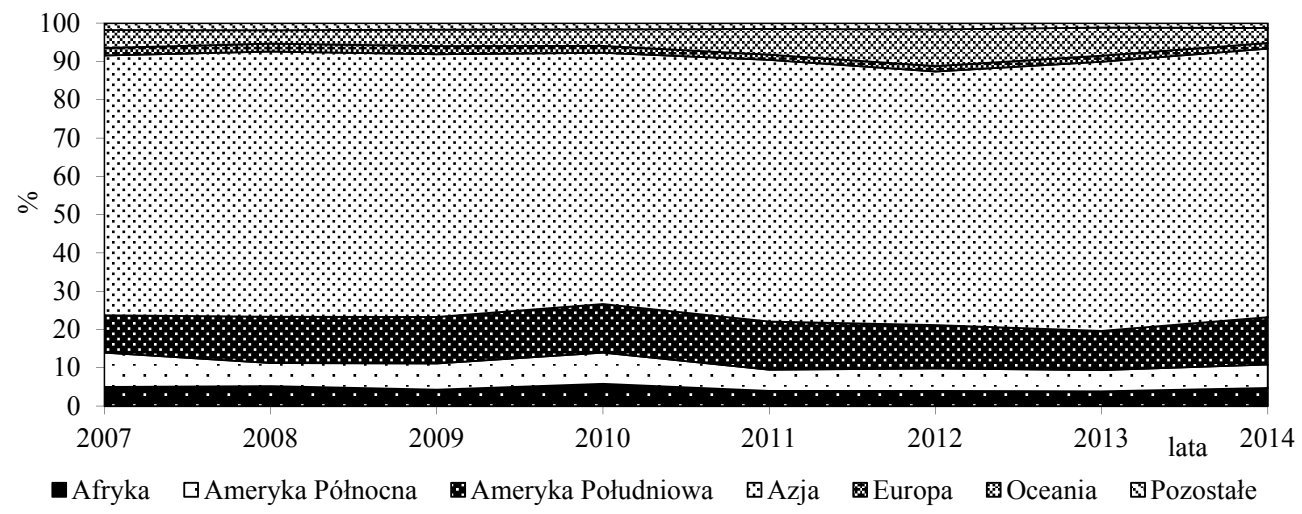

Rys. 5. Udział regionów świata w produkcji nieżywnościowej rolnictwa w latach 2007-2015 (\%)

Fig. 5. Share of world regions in non-food production of agriculture in 2007-2015 (\%)

Źródło: jak w tab. 1.

W przypadku produktów nieżywnościowych uzyskiwanych z rolnictwa występowała największa koncentracja produkcji, spośród wszystkich omawianych grup. W Azji wytwarzano bowiem w 2014 roku 70\% takich produktów. Kolejne miejsca zajmowały Ameryka Południowa (12\%), Ameryka Północna (6\%) i Afryka (5\%). W latach 2007-2014 zwiększył się udział w strukturze tylko w przypadku Azji, Ameryki Południowej.

\section{Podsumowanie}

$\mathrm{W}$ opracowaniu przedstawiono zmiany $\mathrm{w}$ wartości produkcji rolnictwa $\mathrm{w}$ regionach świata. Taki poziom makro pozwala zaobserwować pewne prawidłowości. Wartość światowej produkcji rolniczej stale wzrastała. Jedynie w momencie kryzysu gospodarczego w 2009 roku oraz w 2014 roku zaobserwowano spadki we wszystkich obszarach poza Azją. Zauważono, że występowała duża koncentracja produkcji rolniczej, która była skupiona w Azji i Europie. Następowało stopniowe przenoszenie się produkcji z Europy i Ameryki Północnej do Azji i Ameryki Południowej. Prawidłowości te zostały potwierdzone również przy analizie poszczególnych grup produktów rolnych, jak zboża i produkty zwierzęce. Jednocześnie stwierdzono bardzo dużą koncentrację i występowanie dużego zróżnicowania produkcji rolniczej w regionach, o czym świadczy obliczony współczynniki Giniego oraz krzywa koncentracji Lorenza.

Przedstawienie danych dla dosyć krótkiego okresu pokazuje kierunki zmian. Dysproporcje wzrastały szybciej $\mathrm{w}$ przypadku produktów żywnościowych niż nieżywnościowych wytworzonych w rolnictwie. Na taką sytuację ma wpływ polityka rolna, która np. ogranicza wzrost produkcji w UE, zaś jest liberalna w poszczególnych państwach azjatyckich i południowoamerykańskich. Dodatkowo naturalne warunki przyrodnicze i niski koszt produkcji są kolejnymi czynnikami, które preferują regiony Azji i Ameryki Południowej oraz Oceanii. W przypadku tego ostatniego regionu skala działalności była jednak zbyt mała, aby był on znaczącym obszarem w światowej produkcji rolniczej. 
Ciągle dominującym przeznaczeniem surowców pozyskiwanych w rolnictwie jest wytwarzanie żywności. Zaledwie 4-5\% przeznaczano na produkty nieżywnościowe. Tempo zmian wartości produktów nieżywnościowych z rolnictwa było podobne, jak produktów żywnościowych. W tym przypadku produkcja była skoncentrowana w Azji, gdzie wytwarzano około 70\% wyrobów nieżywnościowych.

Globalizacja dotyczy również rolnictwa. Sprawia, że produkcja rolna jest stopniowo przenoszona do regionów charakteryzujących się najlepszymi warunkami i kosztami produkcji. Oczywiście w ramach wydzielonych regionów obejmujących kontynenty występuje duże zróżnicowanie między krajami. Analizy dotyczące zależności międzynarodowych mogą być więc przedmiotem pogłębionych badań. Może się okazać, że w regionie Azja są kraje, gdzie odnotowywano duży wzrost produkcji rolniczej, ale też obszary ze spadkiem tej produkcji. Przedstawione opracowanie ma zobrazować kierunki zmian w ujęciu makro.

\section{Literatura}

Adamowicz, M. (2008). Teoretyczne uwarunkowania rozwoju rolnictwa z uwzględnieniem procesów globalizacji i międzynarodowej integracji. Roczniki Nauk Rolniczych. Seria G, Ekonomika Rolnictwa, 94(2), $49-64$.

Anioł, A., Bielecki, S., Twardowski, T. (2008). Genetycznie zmodyfikowane organizmy - szanse i zagrożenia dla Polski. Nauka, 1, 63-84.

Argent, N. (2011). Australian agriculture in the global economic mosaic. W: Globalisation, agriculture and development: Perspectives from the Asia-Pacific, 9-10.

Budnikowski, A. (2003). Międzynarodowe stosunki gospodarcze wobec wyzwań globalizacji. Bank $i$ Kredyt, 1 , dodatek ,Globalizacja od A do Z”.

Dane FAOSTAT. Pobrano w czerwcu 2017 z: http://faostat3.fao.org/home/E, Pobrano.

Kołodko, G.W. (2008). Wędrujący świat. Prószyński i Spółka. Warszawa.

Lubbe, A. (2010). Globalizacja i regionalizacja we współczesnej gospodarce światowej. W: Rozwój w dobie globalizacji red. A. Bąkiewicz, U. Żuławska. Polskie Wydawnictwo Ekonomiczne, Warszawa.

Rigg, J. (2006). Land, farming, livelihoods, and poverty: rethinking the links in the rural South. World Development, 34(1), 180-202.

Rosińska-Bukowska, M. (2009). Rola korporacji transnarodowych w procesach globalizacji. Kreowanie globalnej przestrzeni biznesowej, Wydawnictwo Adam Marszałek-Dom Wydawniczy Duet.

Sapa, A. (2010). Rolnictwo w procesie globalnego rozwoju. W: Rozwój w dobie globalizacji, red. A. Bąkiewicz, U. Żuławska. Polskie Wydawnictwo Ekonomiczne, Warszawa.

Sobiecki, R. (2007). Globalizacja a funkcje polskiego rolnictwa. SGH, Warszawa, s. 11, 84.

Żołądkiewicz, K. (2012). Regionalizacja i regionalizm w gospodarce światowej. W: Globalizacja i regionalizacja w gospodarce światowej, red. R. Orłowska, K. Żołądkiewicz. Polskie Wydawnictwo Ekonomiczne, Warszawa. 